\title{
A Novel Study on Using Vietnam Rice Hush Ash and Cullet as Environmental Materials
}

\author{
PHAM Trung Kien ${ }^{1, *}$, TRAN Thi Thien Ly ${ }^{2,}$, PHAM Thi Lan Thanh ${ }^{3,}$, TRAN Pham Quang \\ Nguyen ${ }^{1}$, NGUYEN Hoc Thang ${ }^{4}$, and Mohd Mustafa Al Bakri ABDULLAH ${ }^{5}$ \\ ${ }^{1}$ Faculty of Materials Technology, Ho Chi Minh City University of Technology (HCMUT), Vietnam \\ National University (VNUHCM) 268 Ly Thuong Kiet, District 10, Ho Chi Minh City, Vietnam \\ ${ }^{2}$ Hai Anh Equipment and Technology Co. Ltd. 127/33 Hoang Hoa Tham, District Tan Binh, Ho Chi \\ Minh City, Vietnam \\ ${ }^{3}$ Faculty of Pharmacy, Lac Hong University, 10 Huynh Van Nghe, Dong Nai, Vietnam \\ ${ }^{4}$ Faculty of Chemical Technology, Ho Chi Minh City University of Food Industry, 140 Le Trong \\ Tan, Tan Phu District, Ho Chi Minh City, Viet Nam \\ ${ }^{5}$ Center of Excellence, Geopolymer \& Green Technology (CeGeoGTech), School of Material \\ Engineering, Universiti Malaysia Perlis (UniMAP), Perlis Malaysia
}

\begin{abstract}
This work introduces novel method to prepare ecomaterials wollastonite $\left(\mathrm{CaSiO}_{3}\right)$ using the hydrothermal treatment technique of Rice hush ash (RHA), glass cullet and $\mathrm{CaO}$ at $180^{\circ} \mathrm{C}$ for 24 hour so as the $\mathrm{Ca} / \mathrm{Si}$ molar ration of 1.0. The sample after hydrothermal treatment at $180^{\circ} \mathrm{C}$ for 24 hours is calcined at $1000^{\circ} \mathrm{C}$ to obtained wollastonite $\mathrm{CaSiO}_{3}$. The obtained wollastonite has many applications in biomaterials and thermal insulator. This research also aim to improve the quality of RHA, thus reduce negative impact to environment.
\end{abstract}

\section{Introduction}

Vietnam is an agriculture country, in which produce lot of rice and its by product is rice husk ash (RHA). The RHA is consider as waste of agriculture industry, and treated by burn in the open air. This process cause air pollution, thus attracted Vietnamese researcher to find alternative method to reduce the impact of rice husk ash to environment. The research group in Department of Ceramic Materials aim to reuse rice husk ash as source of Silica $\left(\mathrm{SiO}_{2}\right)$. It need to emphasized that the main content of rice husk ash is silica. In addition, glass cullet also contain up to $70 \%$ of Silica. This research report new technology to mixing RHA with glass cullet and $\mathrm{CaO}$ with the $\mathrm{Ca} / \mathrm{Si}$ molar ratio of 1.0 , in order to synthesize Wollastonite $\left(\mathrm{CaSiO}_{3}\right)$ as environmental materials. Compare with the other method to synthesize wollastonite using chemical reaction between $\mathrm{CaO}$ and $\mathrm{SiO}_{2}$ at $1500^{\circ} \mathrm{C}$ [1-7], the hydrothermal treatment technique require lower temperature. The advantage of our study is utilize the Vietnam RHA and reduce the

* Corresponding author: phamtrungkien@hcmut.edu.vn 


\section{Materials and methods}

\subsection{Preparation of RHA}

Rice husk is burn at $600^{\circ} \mathrm{C}$ with the heating rate of $10^{\circ} \mathrm{C} / \mathrm{min}$ (Naberthem 1400 , Nabertherm, Germany), then soaking at 2 hour for complete burning. The phase composition of obtained RHA is characterized using Xray Diffraction and Fourier transform infrared spectroscopy (FTIR).

\subsection{Preparation of glass cullet}

Glass cullet is supplied by Coca Cola Vietnam. The cullet is pre-milled by hammer milling, then heating at $700^{\circ} \mathrm{C}$ using electric furnace (Nabertherm 1400, Nabertherm, Germany) with the heating rate of $10^{\circ} \mathrm{C} / \mathrm{min}$, soaking at $30 \mathrm{~min}$, quench by tap water to increase the milling ability. The cullet is milled in ball milling machine for 20 mins, and pass the sieve $125 \mu \mathrm{m}$. The chemical composition of obtained RHA is characterized using XRay Flouresence (XRF) method.

\subsection{Preparation of $\mathrm{CaO}$}

$\mathrm{CaO}$ is supplied by Xilong Chemical in bottle $500 \mathrm{~g}$.

\subsection{Preration of mixture}

The mixture of RHA, glass culled and $\mathrm{CaO}$ is mixing with the weight ratio of $\mathrm{CaO}$ : RHA: glass cullet is 1.43: 1.00: 1.00 so that the $\mathrm{Ca} / \mathrm{Si}$ molar ratio of the mixture is 1.0 according to the chemical composition of wollastonite $(\mathrm{CaSiO} 3)$. The obtained mixture is pressing at $25 \mathrm{kG} / \mathrm{cm}^{2}$ to form the disk the diameter of $14 \mathrm{~mm}$ and height of $5 \mathrm{~mm}$, following by hydrothermal treatment at $180^{\circ} \mathrm{C}$ for 6,12 and 24 hours. The hydrothermal treated disk is calcination at $1000^{\circ} \mathrm{C}$ (Nabertherm 1400 , Nabertherm, Germany) to form wollastonite.

\subsection{Phase analysis}

The powder Xray Diffraction (XRD) patterns of disk samples were recorded with a vertically mounted diffractometer system (Bruker-AXS: D8 ADVANCE, Germany) using $\mathrm{Ni}$ filtered $\mathrm{CuKa}$ generated at $15 \mathrm{kV}$.

\subsection{The morphology of samples using Scanning Electron Microscope (SEM)}

The surface of samples were observed using a scanning electron microscope (SEM) (JSM $5400 \mathrm{LV}$, JEOL Co. Ltd., Japan) under an accelerating voltage of $20 \mathrm{kV}$ after being coated with gold.

\subsection{Chemical bonding of sample is analyzed by Fourier Transformer Infrared (FTIR)}

The sample is mixing with $\mathrm{KBr}$ with the ratio 1: 200 and put in the FTIR machine with the waveband vary from $400-4000 \mathrm{~cm}-1$. 


\subsection{Chemical composition of sample is analyzed by Xray-Fluorescence (XRF)}

The sample is energy using Xray (MESA-50, Horiba, Japan) and measure the secondary beam to analyze the chemical composition of sample.

\section{Results and discussions}

The chemical composition of RHA is shown in Table 1:

Table 1. The chemical composition of RHA (weight percent)

\begin{tabular}{|l|l|l|l|l|l|l|l|l|l|l|l|}
\hline $\mathrm{SiO}_{2}$ & $\mathrm{~K}_{2} \mathrm{O}$ & $\mathrm{CaO}$ & $\mathrm{P}_{2} \mathrm{O}_{5}$ & $\mathrm{MgO}$ & $\mathrm{Al}_{2} \mathrm{O}_{3}$ & $\mathrm{MnO}$ & $\mathrm{Fe}_{2} \mathrm{O}_{3}$ & $\mathrm{SO}_{3}$ & other & LOI & Total \\
\hline 92,7 & 3,16 & 1,33 & 0,596 & 0,466 & 0,306 & 0,291 & 0,242 & 0,126 & 0,153 & 0,63 & 100 \\
\hline
\end{tabular}

The phase analysis of RHA is shown in Fig. 1. The main phase compostion of RHA is Cristoballite $\left(\mathrm{SiO}_{2}\right)$ at 2 theta $=22^{\circ}$, as shown in Fig. 1

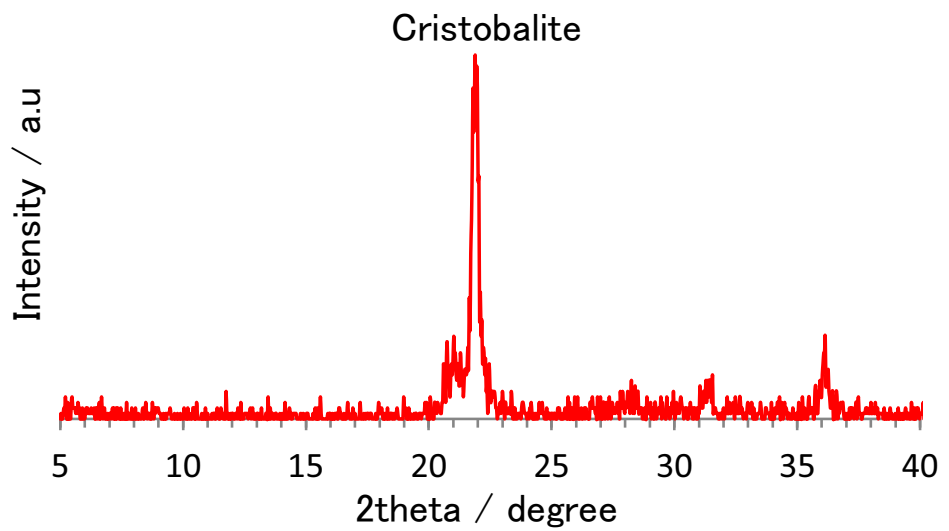

Fig. 1. XRD pattern of RHA, confirm the present of cristobalite at 2 theta $=22^{\circ}$

The chemical bonding of RHA is shown in Fig. 2. This data confirm that the main chemical bonding of RHA is Si-O bonding.

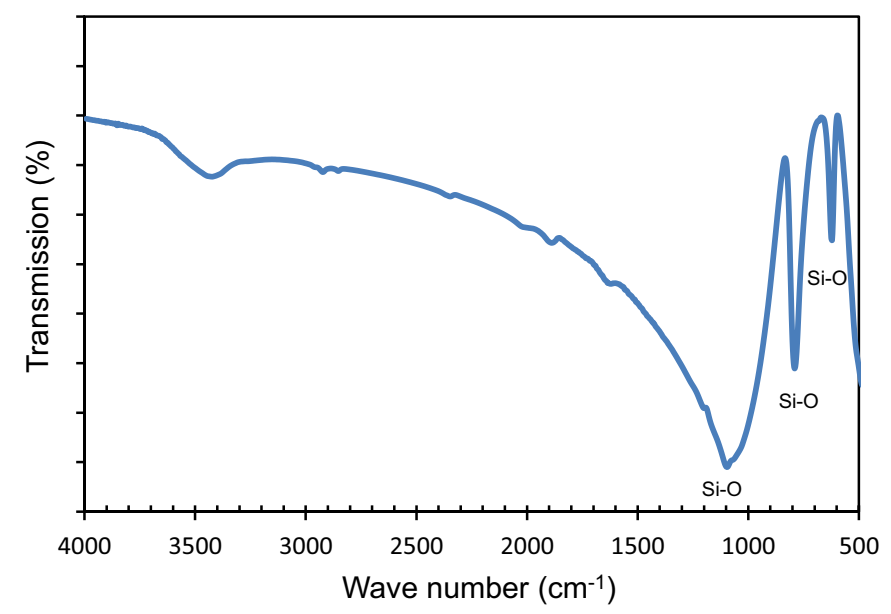

Fig. 2. FTIR of RHA. The bonding of Si-O is display on the figure at 600,700 and $100 \mathrm{~cm}^{-1}$ 
The chemical composition of glass cullet is shown in Table 2:

Table 2. The chemical composition of glass cullet (weight percent)

\begin{tabular}{|l|l|l|l|l|l|l|l|l|l|l|}
\hline $\mathrm{CaO}$ & $\mathrm{SiO}_{2}$ & $\mathrm{Al}_{2} \mathrm{O}_{3}$ & $\mathrm{Fe}_{2} \mathrm{O}_{3}$ & $\mathrm{MgO}$ & $\mathrm{Na}_{2} \mathrm{O}$ & $\mathrm{K}_{2} \mathrm{O}$ & $\mathrm{P}_{2} \mathrm{O}_{5}$ & $\mathrm{TiO}_{2}$ & LOI & Total \\
\hline 10,48 & 70,2 & 1,75 & 0,11 & 0,75 & 13,71 & 0,58 & 0,03 & 0,28 & 2,11 & 100 \\
\hline
\end{tabular}

The SEM of sample hydrothermal treatment at different treatment time $(0 \mathrm{~h}, 6 \mathrm{~h}, 12 \mathrm{~h}$ and 24h) is shown in Fig. 3. We can observe new crystal interlock together at Fig. 3 (c) and (d) to enhance the setting property of sample.
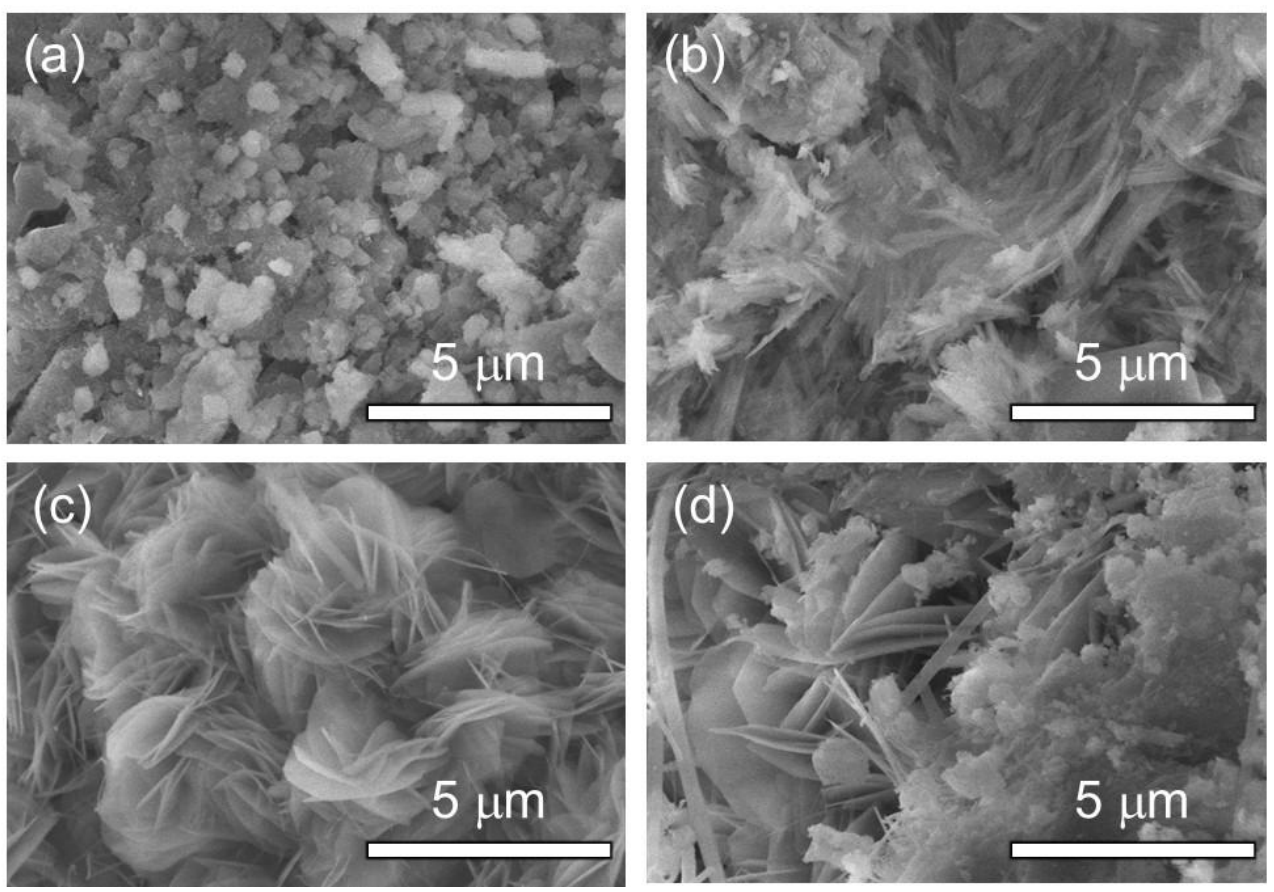

Fig. 3. SEM morphology of mixture hydrothermal treatment at $180^{\circ} \mathrm{C}$ for (a) before (b) $6 \mathrm{~h} \mathrm{(c)} 12 \mathrm{~h}$ and (d) $24 \mathrm{~h}$.

The XRD of sample hydrothermal treatment at different treatment time $(0 \mathrm{~h}, 6 \mathrm{~h}, 12 \mathrm{~h}$ and $24 \mathrm{~h}$ ) is shown in Fig. 4. After hydrothermal treatment, we can observed the peal of Tobermorite at 2 theta $=29^{\circ}$. 


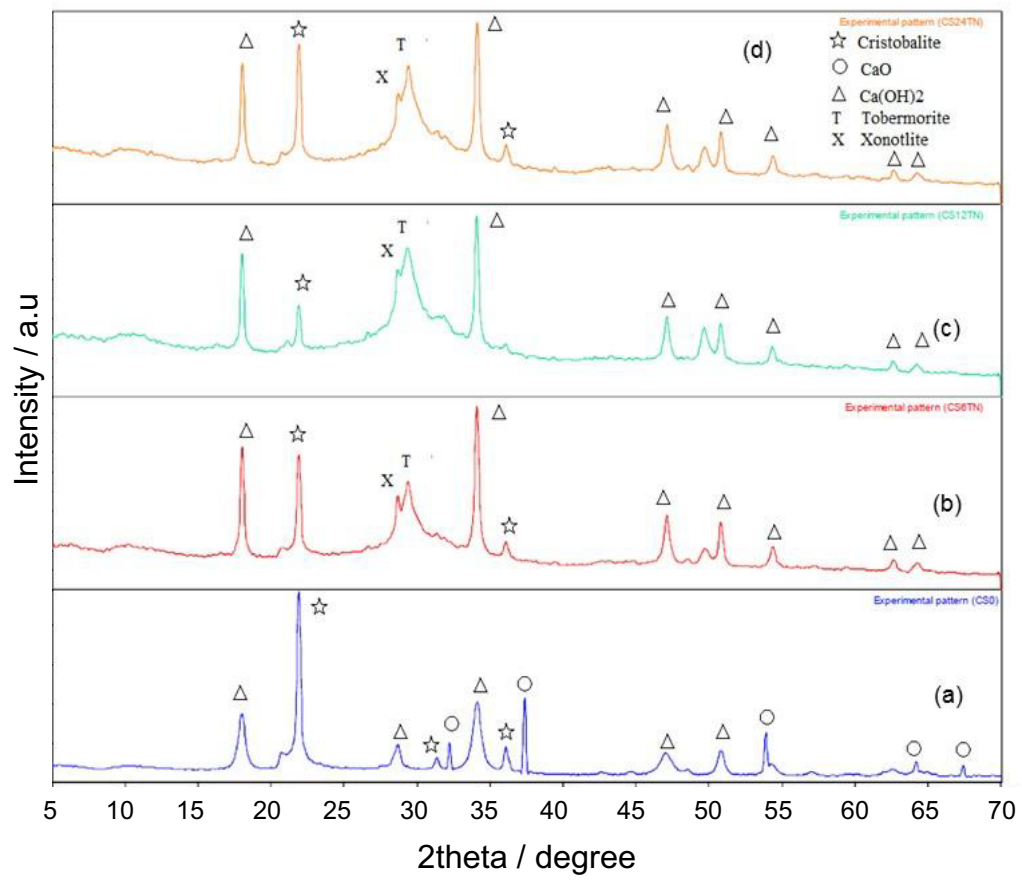

Fig. 4. XRD pattern of sample hydrothermal treatment at $180^{\circ} \mathrm{C}$ for different treatment time: (a) before; (b) $6 \mathrm{~h}$; (c) $12 \mathrm{~h}$ and (d) $24 \mathrm{~h}$

The sample hydrothermal treatment at $180^{\circ} \mathrm{C}$ for $24 \mathrm{~h}$ is calcinated at $1000^{\circ} \mathrm{C}$ to obtain the wollastonite. XRD of wollastonite obtained is shown in Fig. 5.

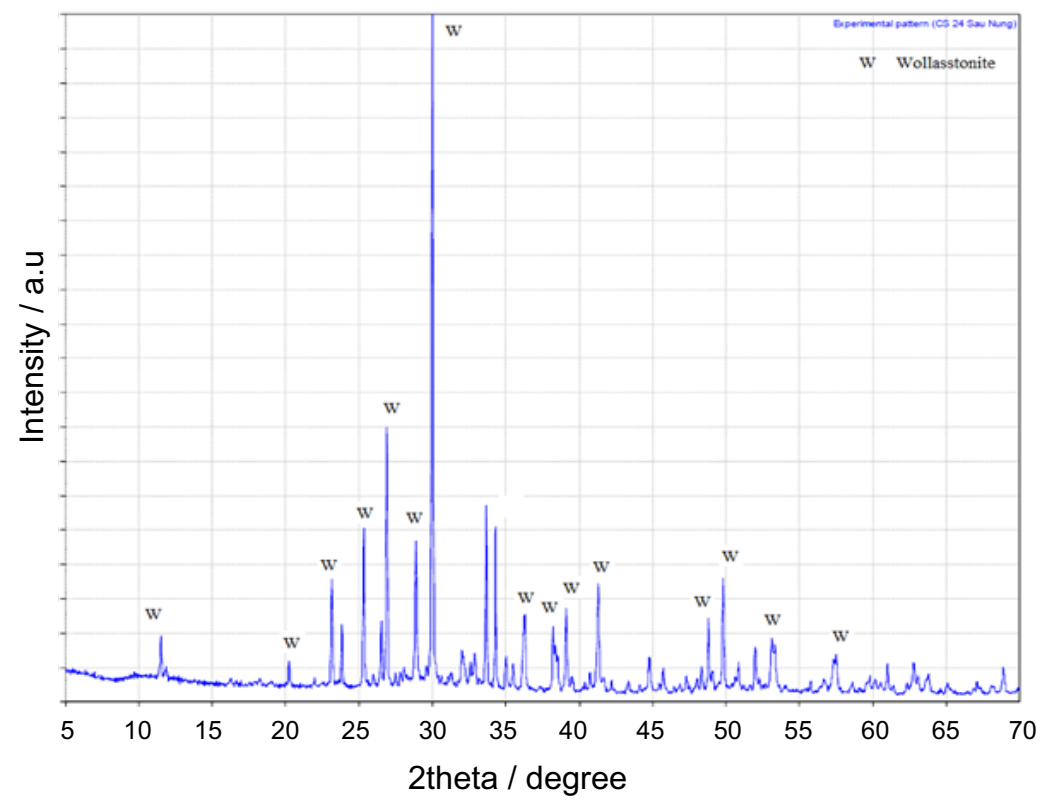

Fig. 5. XRD pattern of sample hydrothermal treatment at $180^{\circ} \mathrm{C}$ for $24 \mathrm{~h}$ then calcination at $1000^{\circ} \mathrm{C}$ to obtain wollastonite (W:Wollastonite). 
Figure 5 shows that we can obtain wollastonite by calcination hydrothermal treatment sample at $1000^{\circ} \mathrm{C}$. The meaning of the study need to put in to the context of our facility. By using hydrothermal treatment of RHA, glass cullet and $\mathrm{CaO}$, following by calcination, we can obtain the wollastonite at $1000^{\circ} \mathrm{C}$. This temperature is much lower than the conventional method. For example, the solid reaction between $\mathrm{CaO}$ and $\mathrm{SiO}_{2}$ to form wollastonite requires the temperature of $1500^{\circ} \mathrm{C}$ or above to happen. The reason that we can lower temperature to form wollastonite from $1500^{\circ} \mathrm{C}$ to $1000^{\circ} \mathrm{C}$ is we utilize the hydrothermal treatment technique. In the other hand, this research is contributing to improve the quality of RHA, thus reduce the negative impact to environment.

\section{Conclusions}

By using hydrothermal treatment technique of mixture of RHA, glass cullet and $\mathrm{CaO}$, following by calcination at $1000^{\circ} \mathrm{C}$, my research group can obtain wollastonite $(\mathrm{CaSiO} 3)$ at low temperature. The obtained wollastonite has many applications in biomaterials and thermal insulator. This research also aim to improve the quality of RHA, thus reduce negative impact to environment. Further application of wollastonite in biomaterials is still under investigated by my group.

This research is funded by Vietnam National University Ho Chi Minh City University of Technology (VNU-HCMUT) under grant number T-CNVL-2016-12". The first author also thankful to Lac Hong University and Center of Excellence, Geopolymer \& Green Technology (CeGeoGTech), School of Material Engineering, Universiti Malaysia Perlis (UniMAP) for helping on material facility.

\section{References}

1. Tasci, J. Aust. Ceram. Soc., 50, 43 (2014)

2. R. Mathur, A.K. Misra, P. Goel, J. Sci. Ind. Res., 66, 1029 (2007)

3. X. Liu, C. Ding, P. K. Chu, Biomaterials, 25, 1755 (2004)

4. M. H. Tiggemann, D. Tomacheski, F. Celso, V. F. Ribeiro, S. M. B. Nachtigall, Polym. Test., 32, 1373 (2013)

5. A.M. Soliman, M.L. Nehdi, Cem. Concr. Compos., 46, 81 (2014)

6. S. Saadaldin, A. Rizkalla, Dent. Mater., 30, 364 (2014)

7. T. Pham, D. Kieu, M. Do, H. Nguyen, H. Ly, T. Pham, Journal of Science and Technology, 52, 198 (2014) 